3. Zhang, M., Zhao, H., Luo, F., Luo, S. and Shi, W., IGF-II inhibitory DNAzymes inhibit the invasion and migration of hepatocarcinoma cells. Biotechnol. Lett., 2011, 33(5), 911-917.

4. Zhang, M., Drummen, G. P. and Luo, S., Anti-insulin-like growth factor-IIP3 DNAzymes inhibit cell proliferation and induce caspase-dependent apoptosis in human hepatocarcinoma cell lines. Drug Des. Dev. Ther., 2013, 7, 1089-1102.

5. Breuhahn, K. and Schirmacher, P., Reactivation of the insulin-like growth factor-II signaling pathway in human hepatocellular carcinoma. World J. Gastroenterol., 2008, 14(11), 1690-1698.

6. Dass, C. R., Saravolac, E. G., Li, Y. and Sun, L. Q., Cellular uptake, distribution, and stability of 10-23 deoxyribozymes. Antisense Nucleic Acid Drug Dev., 2002, 12(5), 289-299.

7. Qu, Y. et al., Effects of DNAzymes targeting Aurora kinase A on the growth of human prostate cancer. Cancer Gene Ther., 2008, 15(8), 517-525

8. Niewiarowska, J., Sacewicz, I., Wiktorska, M., Wysocki, T., Stasikowska, O., Wagrowska-Danilewicz, M. and Cierniewski, C. S., DNAzymes to mouse beta1 integrin mRNA in vivo: targeting the tumor vasculature and retarding cancer growth. Cancer Gene Ther., 2009, 16(9), 713-722.

9. Dass, C. R., Galloway, S. J. and Choong, P. F., Dz13, a c-jun DNAzyme, is a potent inducer of caspase-2 activation. Oligonucleotides, 2010, 20(3), 137-146.

10. Benard, V., Bohl, B. P. and Bokoch, G. M., Characterization of rac and cdc42 activation in chemoattractant-stimulated human neutrophils using a novel assay for active GTPases. J. Biol. Chem., 1999, 274(19), 13198-13204.

11. Zhou, H. et al., RNAi targeting urokinase-type plasminogen activator receptor inhibits metastasis and progression of oral squamous cell carcinoma in vivo. Int. J. Cancer, 2009, 125(2), $453-462$.

12. Abellan, R. et al., Immunoassays for the measurement of IGF-II, IGFBP-2 and -3 , and ICTP as indirect biomarkers of recombinant human growth hormone misuse in sport. Values in selected population of athletes. J. Pharm. Biomed. Anal., 2008, 48(3), 844852.

13. Sel, M. et al., Effective prevention and therapy of experimental allergic asthma using a GATA-3-specific DNAzyme. J. Allergy Clin. Immunol., 2008, 121, 910-916.

14. Schubert, S., Gul, D. C., Grunert, H. P., Zeichhardt, H., Erdmann, V. A. and Kurreck, J., RNA cleaving '10-23' DNAzymes with enhanced stability and activity. Nucleic Acids Res., 2003, 31(20), 5982-5992.

15. Hallett, M. A., Teng, B., Hasegawa, H., Schwab, L. P., Seagroves, T. N. and Pourmotabbed, T., Anti-matrix metalloproteinase-9 DNAzyme decreases tumor growth in the MMTV-PyMT mouse model of breast cancer. Breast Cancer Res., 2013, 15(1), R12.

ACKNOWLEDGEMENTS. This work was partially supported by the Health Department of Jilin Province (No. 2013ZC029, Chun Li Mei and Min Zhang); the Health Department of Jilin Province (No. 2014Q003, Liu Ji dong and Min Zhang); the National Natural Science Foundation of China (No. 81541168, Min Zhang and Chun Li Mei); and the Education Department of Jilin Province in China (No. 2015153, Chun Li Mei and Min Zhang).

Received 27 March 2018; revised accepted 1 March 2019

doi: $10.18520 / \mathrm{cs} / \mathrm{v} 116 / \mathrm{i} 12 / 2072-2077$

\section{Fluoride removal by novel composite material and its performance in the fixed-bed column filter}

\author{
Mahipal ${ }^{1}$, Hasan Ahmed Faisal ${ }^{1}$, Arkamitra Kar ${ }^{2}$ \\ and Trishikhi Raychoudhury ${ }^{1, *}$ \\ ${ }^{1}$ Department of Civil and Environmental Engineering, \\ Indian Institute of Technology Patna, Bihta, Patna 801 103, India \\ ${ }^{2}$ Department of Civil Engineering, BITS-Pilani Hyderabad Campus, \\ Jawahar Nagar, Hyderabad 500 078, India
}

The objectives of this study are to (i) evaluate the process controlling fluoride $\left(\mathrm{F}^{-}\right)$removal by ceriumimpregnated activated carbon (AC-Ce) composite, and (ii) assess the performance of that composite in the fixed-bed column as a filter. The AC-Ce composites were synthesized by collecting $\mathrm{AC}$ from different sources $\left(A C_{\text {Darco }}\right.$ and $\left.A C_{E c o}\right)$. The observations from this study suggest that the homogeneous distribution of amorphous Ce within $\mathrm{AC}_{\text {Darco }}-\mathrm{Ce}$ results in high $\mathrm{F}^{-}$ sorption. Formation of crystalline $\mathrm{CeO}_{2}$ and small pore size of $\mathrm{AC}_{\mathrm{Eco}}$ inhibits $\mathrm{F}^{-}$sorption by $\mathrm{AC}_{\mathrm{Eco}}-\mathrm{Ce}$. The $\mathrm{AC}_{\text {Darco }}-\mathrm{Ce}$ composite in fixed-bed filter media can treat up to $722 \mathrm{ml}$ of $\mathrm{F}^{-}$contaminated water.

Keywords: Activated carbon, cerium, composite material, fixed-bed column, fluoride removal.

FLUORIDE $\left(\mathrm{F}^{-}\right)$contamination in groundwater is a major problem in many parts of the world. The accepted limit of $\mathrm{F}^{-}$concentration in drinking water is $1.5 \mathrm{mg} / \mathrm{l}$. Aluminabased adsorbent and precipitate are commonly used for defluoridation of water. However, leaching of aluminium from the adsorbent is a major concern for its application ${ }^{1}$. In recent years, several studies have focused on developing novel composites and nanomaterials as adsorbents for defluoridation of water. For example, zirconiumimpregnated collagen fibre ${ }^{2}, \mathrm{Mg}-\mathrm{Al}-\mathrm{Zr}$ triple-metal composite $^{3}$, metal-impregnated granular activated carbon $(\mathrm{AC})^{4-6}$, alum-impregnated activated alumina ${ }^{7}$ are synthesized and applied for removal of $\mathrm{F}^{-}$from water. Several recent studies have demonstrated that cerium $(\mathrm{Ce})$, either used in nano-particulate or composite form, exhibits excellent performance in removing $\mathrm{F}^{-}(4.37-153 \mathrm{mg} / \mathrm{g})^{4,7-9}$. Granular AC is also applied widely as a filtering material for water purification, due to its high specific surface area (SSA) and good mechanical resistance. The surface of carbon granule can be modified with metal-based functional groups, which have a strong affinity towards $\mathrm{F}^{-}$ (ref. 1). This modification of AC with metal not only improves the $\mathrm{F}^{-}$removal efficiency, but due to its high mechanical resistance the composite can also be used directly as filter medium in a fixed-bed column. One of

*For correspondence. (e-mail: trishikhi@iitp.ac.in) 
our recent studies shows that cerium-impregnated activated carbon (AC-Ce) composite performs efficiently $(4.60 \mathrm{mg} / \mathrm{g})$ in removing $\mathrm{F}^{-}$from water ${ }^{4}$.

There is scope to explore the possibility of using locally available, green and cheap AC in preparing novel composites, and to assess the process controlling $\mathrm{F}^{-}$removal by these composites. The composite material must be used in a fixed-bed column as a filter. The objectives of this study are to (i) evaluate the process controlling $\mathrm{F}^{-}$removal efficiency by $\mathrm{AC}-\mathrm{Ce}$ composites and (ii) assess the performance of these composites for $\mathrm{F}^{-}$removal in a fixed-bed column as a filter. To achieve these objectives the $\mathrm{AC}-\mathrm{Ce}$ composites were synthesized, where $\mathrm{AC}$ was obtained from different sources. The $\mathrm{F}^{-}$removal mechanism by different AC-Ce composites was assessed by characterizing the composites and water through several experimental techniques. The performance of the composites within a 1D fixed-bed column filter was assessed to identify the practical applicability of the proposed technique.

Granular AC prepared by Norit-Darco (Sigma-Aldrich, India) ( $\mathrm{AC}_{\text {Darco }}$ : $12-20 \mathrm{mesh}$, size: $\left.850-1000 \mu \mathrm{m}\right)$, sodium fluoride $(\mathrm{NaF})$, and cerium nitrate $\left(\mathrm{Ce}(\mathrm{NO})_{3} \cdot 6 \mathrm{H}_{2} \mathrm{O}\right)$ were obtained from Sigma-Aldrich. Another type of AC, synthesized from coconut shell, was obtained from Global Ecocarb Pvt Ltd, Bengaluru $\left(\mathrm{AC}_{\mathrm{Eco}}\right)$. Milli-Q de-ionized (DI) water was used for all the experiments.

Cerium was impregnated within both granular $\mathrm{AC}$ sources $\left(\mathrm{AC}_{\text {Darco }}\right.$ and $\left.\mathrm{AC}_{\mathrm{Eco}}\right)$ to prepare $\mathrm{AC}_{\text {Darco }}-\mathrm{Ce}$ and $\mathrm{AC}_{\mathrm{Eco}}-\mathrm{Ce}$ composites respectively, following the protocol reported in the literature ${ }^{4,5,10,11}$. As a first step, the AC granules were sieved and washed with DI water several times to remove dust particles and other impurities. The cleaned $\mathrm{AC}$ was then dried overnight for $18 \mathrm{~h}$ at $70^{\circ} \mathrm{C}$. Next $250 \mathrm{ml}$ of $0.03 \mathrm{M}$ cerium nitrate solution was added in a series of conical flasks, each containing $10 \mathrm{~g}$ of $\mathrm{AC}$. The cerium nitrate-AC mixture was then stabilized for a period of $22 \mathrm{~h}$ at $30^{\circ} \mathrm{C}$. After equilibrium was attained, the excess solutions were discarded and the granule was rinsed with DI water. Then the $\mathrm{AC}-\mathrm{Ce}$ mix was dried at $60^{\circ} \mathrm{C}$ for a period of $24 \mathrm{~h}$. The synthesized $\mathrm{AC}_{\text {Darco }}-\mathrm{Ce}$ and $\mathrm{AC}_{\mathrm{Eco}}-\mathrm{Ce}$ composites were stored under airtight condition. The effects of various synthesis conditions such as $\mathrm{pH}$ of the solution, salt concentration, temperature and metal composition have been examined in our earlier stu$\operatorname{dies}^{4,5}$. Based on the results of those studies, the optimal synthesis condition (as mentioned above) was adopted in the present study. Four different batches of each type of AC-Ce composites were synthesized under identical synthesis conditions to ensure reproducibility of the composites.

The morphology and chemical element analysis at the surface of the samples was performed using a scanning electron microscope (SEM) attached with energy dispersive X-ray spectroscopy (EDS; Carl Zeiss EVO 50, Germany).
The cerium content (wt $\%$ ) of the samples was analysed using Induced Coupled Plasma Mass Spectroscopy (ICPMS) (7800 ICP-MS, Agilent Technologies, USA). The unmodified $\mathrm{AC}$ and composites were acid digested using a microwave digester (Advanced Microwave Digestion System, Milestone, USA) following the protocol reported elsewhere (EPA 3015 A).

$\mathrm{X}$-ray diffraction (XRD) analysis of the composites was done using a X-ray diffractometer (TTRAX-3, Rigaku, USA). The scans were performed with a $2 \theta$ interval of $0.01^{\circ}$. The rate of scanning was maintained at $2 \mathrm{sec}$ per step. $\mathrm{Cu}-\mathrm{K}_{\alpha}$ radiation $(5 \mathrm{~kW})$ was used for scanning ${ }^{12}$.

In this study, Brunauer-Emmett-Teller (BET) surface area, pore volume and pore diameter were measured using the BET analyzer (Autosorb 1C, Quantachrome Instruments, USA). The samples were degassed at $200^{\circ} \mathrm{C}$ under vacuum before performing the $\mathrm{N}_{2}$ adsorptiondesorption experiment.

The surface chemical bond of the prepared composites under different conditions was studied using Fourier Transform Infrared Spectroscopy (FTIR, Avatar 370, Thermo Nicolet, USA). The samples were subjected to infrared radiation, and transmission spectra were recorded with wavenumbers ranging from 4000 to $400 \mathrm{~cm}^{-1}$ (ref. 12).

The point of zero charge $\left(\mathrm{pH}_{\mathrm{PZC}}\right)$ for both $\mathrm{AC}_{\text {Darco }}-\mathrm{Ce}$ and $\mathrm{AC}_{\mathrm{Eco}}-\mathrm{Ce}$ composites was determined using $\mathrm{pH}$ drift $\operatorname{method}^{13}$. A $0.01 \mathrm{M} \mathrm{NaCl}$ solution was prepared and purged with nitrogen to expel the dissolved $\mathrm{CO}_{2}$. Then, $50 \mathrm{ml} \mathrm{NaCl}$ solution was poured in a series of tubes and $\mathrm{pH}$ of the solutions in different tubes was adjusted within the range $2-10(2,4,6,8$ and 10) using either $\mathrm{HCl}$ or $\mathrm{NaOH}$ solution. In each of the tubes, $0.1 \mathrm{~g}$ of the composite was added. The samples were mixed for $24 \mathrm{~h}$ under airtight condition at $25 \mathrm{rpm}$ and then the solution was filtered before measuring its final $\mathrm{pH}$. The results are represented as the absolute difference between the final and initial $\mathrm{pH}$ values $(|\Delta \mathrm{pH}|)$ with respect to the initial $\mathrm{pH}$ value. The point of zero charge is where the value of $|\Delta \mathrm{pH}|$ is 0 .

Fluoride removal efficiency by $\mathrm{AC}_{\text {Darco }}-\mathrm{Ce}$ and $\mathrm{AC}_{\mathrm{Eco}}-$ Ce composites was assessed in the batch system. In the first step, the stock solution of $\mathrm{F}^{-}(100 \mathrm{mg} / \mathrm{l} \mathrm{F})$ was prepared from $\mathrm{NaF}$ salt and diluted to $10 \mathrm{mg} / \mathrm{l}$ of $\mathrm{F}^{-}$. The measured $\mathrm{pH}$ of this solution was $8.0 \pm 0.3$. Then, $50 \mathrm{ml}$ of $10 \mathrm{mg} / \mathrm{l}$ of $\mathrm{F}^{-}$contaminated water was added to polyethylene tubes, each containing $0.1 \mathrm{~g}$ of $\mathrm{AC}-\mathrm{Ce}$ composites or AC granules. The adsorbent dose was maintained the same as reported in previous studies ${ }^{4-6}$. The tubes were kept in a horizontal position for $3 \mathrm{~h}$ and shaken at regular intervals. The samples were withdrawn from each tube at the end of $3 \mathrm{~h}$ for analysis. All the experiments were performed in triplicate, and the results are presented below.

Results obtained from the above experiments suggest that $\mathrm{F}^{-}$removal efficiency of $\mathrm{AC}_{\text {Darco }}-\mathrm{Ce}$ composite is 

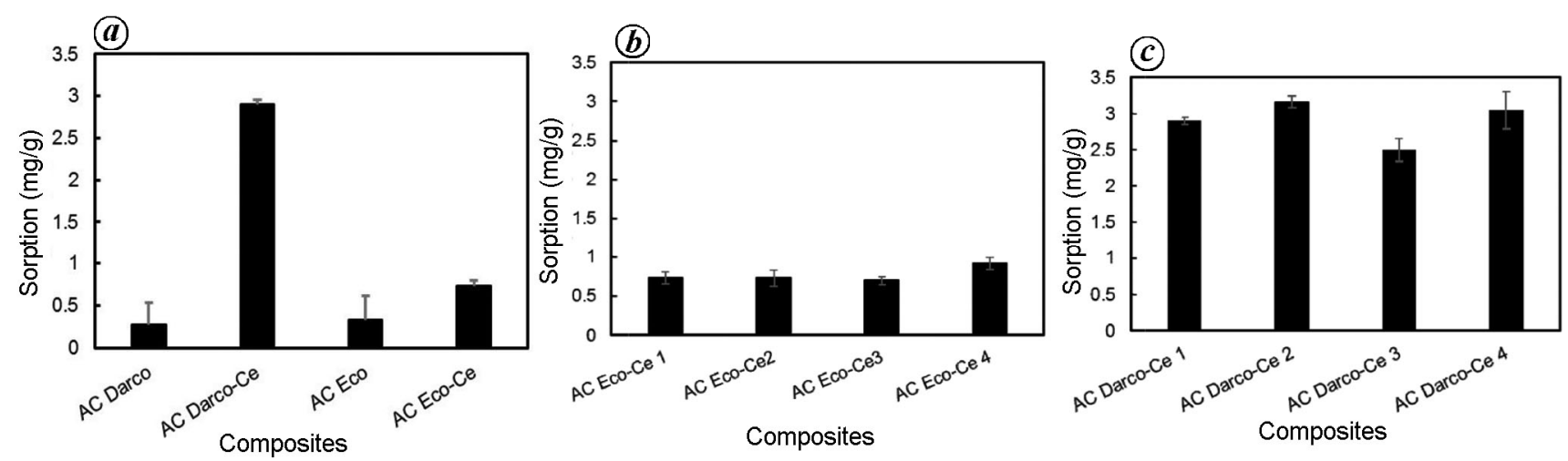

Figure 1. $\boldsymbol{a}$, Fluoride removal efficiency by different cerium-impregnated activated carbon (AC-Ce) composites. $\boldsymbol{b}, \boldsymbol{c}$, Performance of the composites reproduced in four different batches: $(\boldsymbol{b}) \mathrm{AC}_{\mathrm{Eco}}-\mathrm{Ce}$ composites and (c) $\mathrm{AC}_{\mathrm{Darco}}-\mathrm{Ce}$ composites. Initial $\mathrm{F}^{-}$and composite concentrations were $10 \mathrm{mg} / \mathrm{l}$ and $2 \mathrm{~g} / 1$ respectively.

significantly higher compared to $\mathrm{AC}_{\mathrm{Eco}}-\mathrm{Ce}$ composite. Thus, for the packed column experiment, only $\mathrm{AC}_{\text {Darco }}$ Ce composite was selected as the model adsorbent.

A glass column (Chromaflex, Kimble, USA) of $15 \mathrm{~cm}$ length and $1 \mathrm{~cm}$ internal diameter (ID) was used as a fixed-bed column. The $\mathrm{AC}_{\text {Darco }}-\mathrm{Ce}$ composite was packed within the column using the protocol reported elsewhere ${ }^{14}$. Then $10 \mathrm{mg} / 1$ of $\mathrm{F}^{-}$containing DI water was injected at a flow rate of $0.6 \mathrm{ml} / \mathrm{min}$ from the bottom of the column. The sample was collected from the top of the column for analysis. The $\mathrm{F}^{-}$contaminated water was injected until $\mathrm{F}^{-}$concentration at the outlet reached $1.5 \mathrm{mg} / \mathrm{l}$.

For sample analysis, few samples taken from batch experiments were centrifuged at $2000 \mathrm{rpm}$ (5804R, Eppendorf, Germany) before measuring the concentration of $\mathrm{F}^{-}$. The negligible effect of centrifugation was observed on the measured concentration of $\mathrm{F}^{-}$. This suggested the absence of $\mathrm{AC}-\mathrm{Ce}$ dust and/precipitate containing $\mathrm{F}^{-}$ in the solution after sorption experiment, and thus centrifugation was not included in the sample analysis protocol. The $\mathrm{F}^{-}$concentration was measured using a fluoride ion selective electrode (ISE, Orion STAR A214, ThermoScientific, USA). Total ionic strength adjustment buffer (TISAB) solution was added to the sample in the ratio $1: 10$ prior to $\mathrm{F}^{-}$measurement. The results and discussions are presented below.

Sorption experiments were carried out with a sorbent dose of $2 \mathrm{~g} / \mathrm{l}$ and $\mathrm{F}^{-}$concentration of $10 \mathrm{mg} / \mathrm{l}$. The result of batch experiments indicates that $\mathrm{F}^{-}$removal efficiency by $\mathrm{AC}_{\mathrm{Eco}}(0.33 \pm 0.30 \mathrm{mg} / \mathrm{g})$ and $\mathrm{AC}_{\text {Darco }}(0.28 \pm$ $0.2 \mathrm{mg} / \mathrm{g}$ ) is in the same range. The sorption capacity of the $\mathrm{AC}_{\text {Darco }}-\mathrm{Ce}$ composites increases significantly (from 0.28 to $2.90 \mathrm{mg} / \mathrm{g}$ ) when $\mathrm{Ce}$ is impregnated within $\mathrm{AC}_{\text {Darco }}$ (Figure $1 \mathrm{a}$ ). However, there is negligible increase in the $\mathrm{F}^{-}$removal efficiency by $\mathrm{AC}_{\mathrm{Eco}}-\mathrm{Ce}$ composites $(0.70 \mathrm{mg} / \mathrm{g})$ compared to unmodified $\mathrm{AC}_{\mathrm{Eco}}(0.33 \mathrm{mg} / \mathrm{g})$ (Figure $1 \mathrm{a}$ ). The consistent $\mathrm{F}^{-}$removal efficiency by $\mathrm{AC}_{\text {Darco }}-\mathrm{Ce}$ and $\mathrm{AC}_{\mathrm{Eco}}-\mathrm{Ce}$ composites synthesized in dif- ferent batches suggests that the composites are reproducible (Figure $1 b$ and $c$ ). The maximum sorption capacity of $\mathrm{AC}_{\text {Darco }}-\mathrm{Ce}$ composite is $4.37 \mathrm{mg} / \mathrm{g}$, which was determined in our previous study by fitting the Langmuir model with equilibrium isotherm data ${ }^{5}$. The result shows that the composite is reasonably good in comparison with other composite materials $(1.25-1.95 \mathrm{mg} / \mathrm{g})$ reported in different studies ${ }^{10,15}$.

The sorption capacity of $\mathrm{AC}_{\text {Darco }}-\mathrm{Ce}$ composite is much better than $\mathrm{AC}_{\mathrm{Eco}}-\mathrm{Ce}$ composite. This observation could be explained by the fact that the different sources of AC have different characteristics.

The point of zero charge for both $\mathrm{AC}_{\text {Darco }}-\mathrm{Ce}$ and $\mathrm{AC}_{\mathrm{Eco}}-\mathrm{Ce}$ composites was found to be 4 and 6 respectively (Figure $2 b$ ). This suggests that the net surface charge for $\mathrm{AC}_{\text {Darco }}-\mathrm{Ce}$ composite is likely to be positive below a $\mathrm{pH}$ value of 4 and negative above it. A similar trend is expected for $\mathrm{AC}_{\mathrm{Eco}}-\mathrm{Ce}$ composite around $\mathrm{pH}_{\mathrm{PZC}}$ of 6 (ref. 15). In this study, the $\mathrm{pH}$ of $\mathrm{F}^{-}$containing solution (DI water and groundwater) was in the range $8.0 \pm 0.3$, which suggests that both the composites are likely to have a negative net surface charge. Thus, $\mathrm{F}^{-}$(anion) removal due to electrostatic attraction by the composites would be limited $^{12,13}$. This observation is supported by the fact that $\mathrm{F}^{-}$removal efficiency decreases with increase in $\mathrm{pH}$ for $\mathrm{AC}_{\text {Darco }}-\mathrm{Ce}$ composite, as reported in a previous study ${ }^{5}$.

Desorption of nitrate $\left(\mathrm{NO}_{3}^{-}\right)$was observed for both $\mathrm{AC}_{\mathrm{Eco}}-\mathrm{Ce}(9.42 \mathrm{mg} / \mathrm{l})$ and $\mathrm{AC}_{\text {Darco }}-\mathrm{Ce}(13.67 \mathrm{mg} / \mathrm{l}) \mathrm{com}-$ posites under DI water condition (Figure $2 a$ ). The release of $\mathrm{NO}_{3}^{-}$ions from the $\mathrm{AC}_{\text {Darco }}-\mathrm{Ce}$ composite $(17.8 \mathrm{mg} / \mathrm{l})$ was found to increase during the sorption of $\mathrm{F}^{-}$. This implies that ion exchange probably contribute to $\mathrm{F}^{-}$removal by the $\mathrm{AC}_{\mathrm{Darco}}-\mathrm{Ce}$ composite. Our previous study ${ }^{7}$ showed that the sorption of $\mathrm{AC}_{\text {Darco }}-\mathrm{Ce}$ composite is better explained by Freundlich isotherm model $\left(r^{2}=0.91\right)$, which suggests that the distribution of charge and/adsorptionactive sites on the surface of the composite are heterogeneous. Thus, though the net surface charge on the composite is negative at higher $\mathrm{pH}(8 \pm 0.3)$, there might 

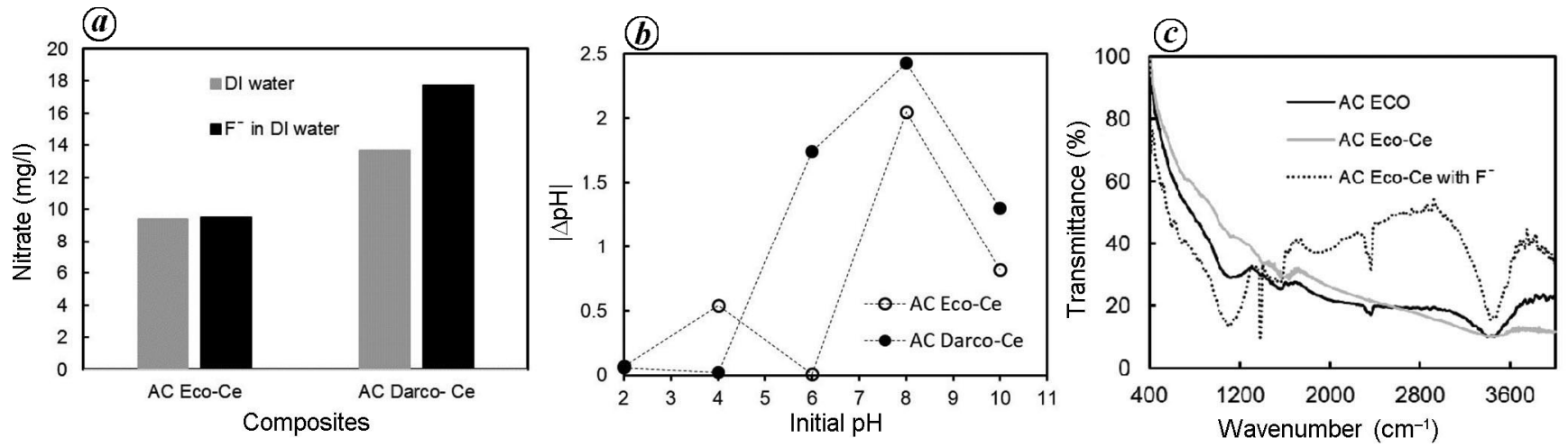

Figure 2. $\boldsymbol{a}$, Nitrate $\left(\mathrm{NO}_{3}^{-}\right)$concentration in water after exposing it to $\mathrm{AC}-\mathrm{Ce}$ composite with or without $\mathrm{F}^{-}$. $\boldsymbol{b}$, Point of zero charge (pH $\mathrm{PZC}_{\text {) }}$ of $\mathrm{AC}_{\text {Darco }}-\mathrm{Ce}$ and $\mathrm{AC}_{\mathrm{Eco}}-\mathrm{Ce}$ composites. $c$, FTIR spectra of $\mathrm{AC}_{\mathrm{Eco}}, \mathrm{AC}_{\mathrm{Eco}}-\mathrm{Ce}$ after and before $\mathrm{F}^{-}$sorption.

be some active sites on the $\mathrm{AC}_{\text {Darco }}-\mathrm{Ce}$ composite for ion exchange. The release of $\mathrm{NO}_{3}^{-}$ions (Figure $2 a$ ) in the presence of $\mathrm{F}^{-}$corroborates the possibility of ion exchange for $\mathrm{AC}_{\text {Darco }}-\mathrm{Ce}$ composite. Furthermore, a sharp decrease in $|\Delta \mathrm{pH}|$ beyond an initial $\mathrm{pH}$ value of 8 (Figure $2 b$ ), probably indicates the occurrence of ion exchange, as suggested elsewhere ${ }^{15}$. On the other hand, no additional release of $\mathrm{NO}_{3}^{-}$ions occurs in the presence of $\mathrm{F}^{-}$when $\mathrm{AC}_{\mathrm{Eco}}-\mathrm{Ce}$ composite is used as an adsorbent. It could be inferred from the observation that sorption is the only mechanism responsible for $\mathrm{F}^{-}$removal by the $\mathrm{AC}_{\mathrm{Eco}}-\mathrm{Ce}$ composite, whereas ion exchange along with sorption is attributed to $\mathrm{F}^{-}$removal by the $\mathrm{AC}_{\text {Darco }}-\mathrm{Ce}$ composite.

To evaluate the surface molecular vibrations and chemical bonds between $\mathrm{F}^{-}$and $\mathrm{AC}-\mathrm{Ce}$ composite, FTIR analysis was performed. The broad absorbance bands at 3399 and $2363 \mathrm{~cm}^{-1}$ observed in the FTIR spectra for $\mathrm{AC}_{\mathrm{Eco}}$ (Figure $2 c$ ) can be assigned to the stretching vibration of the $-\mathrm{OH}$ group ${ }^{16,17}$. The peaks at 1560,1508 and $1116 \mathrm{~cm}^{-1}$ indicate the presence of $\mathrm{C}=\mathrm{C}, \mathrm{C}=\mathrm{O}$ and $\mathrm{C}-\mathrm{O}-\mathrm{C}$ stretching vibrations respectively ${ }^{17}$. After $\mathrm{Ce}$ impregnation, the change in intensity of the peak at 1097 and $472 \mathrm{~cm}^{-1}$ indicates the presence of $\mathrm{Ce}-\mathrm{OH}$ (ref. 18) and $\mathrm{Ce}-\mathrm{O}$ (ref. 19) bonds respectively. After $\mathrm{F}^{-}$sorption, a peak appears at $1383 \mathrm{~cm}^{-1}$ indicating the formation of weak $-\mathrm{CF}_{2}$ bond. Furthermore, the peak intensity at $1097 \mathrm{~cm}^{-1}$ corresponding to $\mathrm{Ce}-\mathrm{OH}$ bond changes after $\mathrm{F}^{-}$sorption, indicating the replacement of $\mathrm{OH}^{-}$by $\mathrm{F}^{-}$. FTIR analysis of $\mathrm{AC}_{\text {Darco }}-$ impregnated metal indicates that the removal of $\mathrm{F}^{-}$by the composite is mainly due to the formation of metal hydroxides at the surface of the composite and by weak $-\mathrm{CF}_{2}$ bonding ${ }^{5}$. So, the type of surface chemical bonding between $\mathrm{AC}_{\mathrm{Eco}}-\mathrm{Ce}$ composite and $\mathrm{F}^{-}$is similar to that of $\mathrm{AC}_{\text {Darco }}-\mathrm{Ce}$ composite and $\mathrm{F}^{-}$. However, the mass of crystalline $\mathrm{CeO}_{2}$ is higher in $\mathrm{AC}_{\mathrm{Eco}}-\mathrm{Ce}$ composite, whereas surface coverage of amorphous $\mathrm{Ce}-\mathrm{OH}$ is likely to be high for $\mathrm{AC}_{\text {Darco }}-\mathrm{Ce}$ composite. The hydroxide of $\mathrm{Ce}$ is more active in removing $\mathrm{F}^{-}$compared to $\mathrm{Ce}-\mathrm{O}$ (ref. 18). Thus, though in both cases sorption is attributed to the removal of $\mathrm{F}^{-}$, the extent of sorption is greater for $\mathrm{AC}_{\text {Darco }}-$ Ce compared to $\mathrm{AC}_{\mathrm{Eco}}-\mathrm{Ce}$ composite.

The irregular morphology of $\mathrm{AC}_{\text {Darco }}$ and was identified from SEM image analysis, which did not change after $\mathrm{Ce}$ impregnation (Figure $3 a$ and $b$ ). On the other hand, surface roughness of $\mathrm{AC}_{\mathrm{Eco}}$ was found to be less predominant. Furthermore, surface morphology of the $\mathrm{AC}_{\mathrm{Eco}}-$ Ce composite was more uniform and crystalline in nature after Ce impregnation (Figure $3 c$ and $d$ ). Presence of Ce was confirmed from the EDS spectra (figure not shown) for both the composites, indicating that it has been was successfully impregnated. Both EDS and ICP-MS analyses indicated that the mass of $\mathrm{Ce}$ impregnated in $\mathrm{AC}_{\mathrm{Eco}}-\mathrm{Ce}$ composite $(0.026 \mathrm{mg} / \mathrm{g}$ from ICP-MS) was much higher than that in $\mathrm{AC}_{\text {Darco }}-\mathrm{Ce}$ composite $(0.016 \mathrm{mg} / \mathrm{g})$. This is likely due to the formation of crystalline $\mathrm{CeO}_{2}$ in $\mathrm{AC}_{\mathrm{Eco}}-$ Ce composite.

$\mathrm{XRD}$ analysis showed that there was no change in the peaks in $\mathrm{AC}_{\text {Darco }}-\mathrm{Ce}$ composite in comparison with $\mathrm{AC}_{\text {Darco }}$ (Figure $3 e$ ), indicating that the impregnated Ce was probably in the amorphous phase. Furthermore, presence of silica was identified in $\mathrm{AC}_{\text {Darco, }}$ which was also confirmed by EDS analysis (not shown here). Two distinct peaks at $2 \theta$ values of $28.9^{\circ}$ and $47^{\circ}$ appeared in the diffractogram for $\mathrm{AC}_{\mathrm{Eco}}-\mathrm{Ce}$ composite (Figure $3 f$ ), which were attributed to the formation of crystalline $\mathrm{CeO}_{2}$ during synthesis of the composite ${ }^{18}$. Formation of crystalline $\mathrm{CeO}_{2}$ within the $\mathrm{AC}_{\mathrm{Eco}}-\mathrm{Ce}$ composite can result in the reduction of $\mathrm{F}^{-}$uptake capacity. From BET analysis, SSA of $\mathrm{AC}_{\mathrm{Eco}}$ was found to be higher $\left(833 \mathrm{~m}^{2} / \mathrm{g}\right)$ than $\mathrm{AC}_{\text {Darco }}$ $\left(334 \mathrm{~m}^{2} / \mathrm{g}\right)$. Impregnation of $\mathrm{Ce}$ in $\mathrm{AC}_{\text {Darco }}$ resulted in a slight increase in $\mathrm{SSA}$, whereas for $\mathrm{AC}_{\mathrm{Eco}}-\mathrm{Ce}$ composite the impregnation of $\mathrm{Ce}$ resulted in a decrease in SSA (from 833 to $759 \mathrm{~m}^{2} / \mathrm{g}$ ) (Table 1). Formation of the crystalline structure of $\mathrm{CeO}_{2}$ as confirmed by XRD and SEM image analyses could be probably attributed to a reduction in $\mathrm{SSA}$ for the $\mathrm{AC}_{\mathrm{Eco}}-\mathrm{Ce}$ composite. In general, SSA of $\mathrm{AC}_{\mathrm{Eco}}-\mathrm{Ce}$ is higher compared to $\mathrm{AC}_{\text {Darco }}-\mathrm{Ce}$ composite. However, $\mathrm{F}^{-}$removal efficiency is less for 

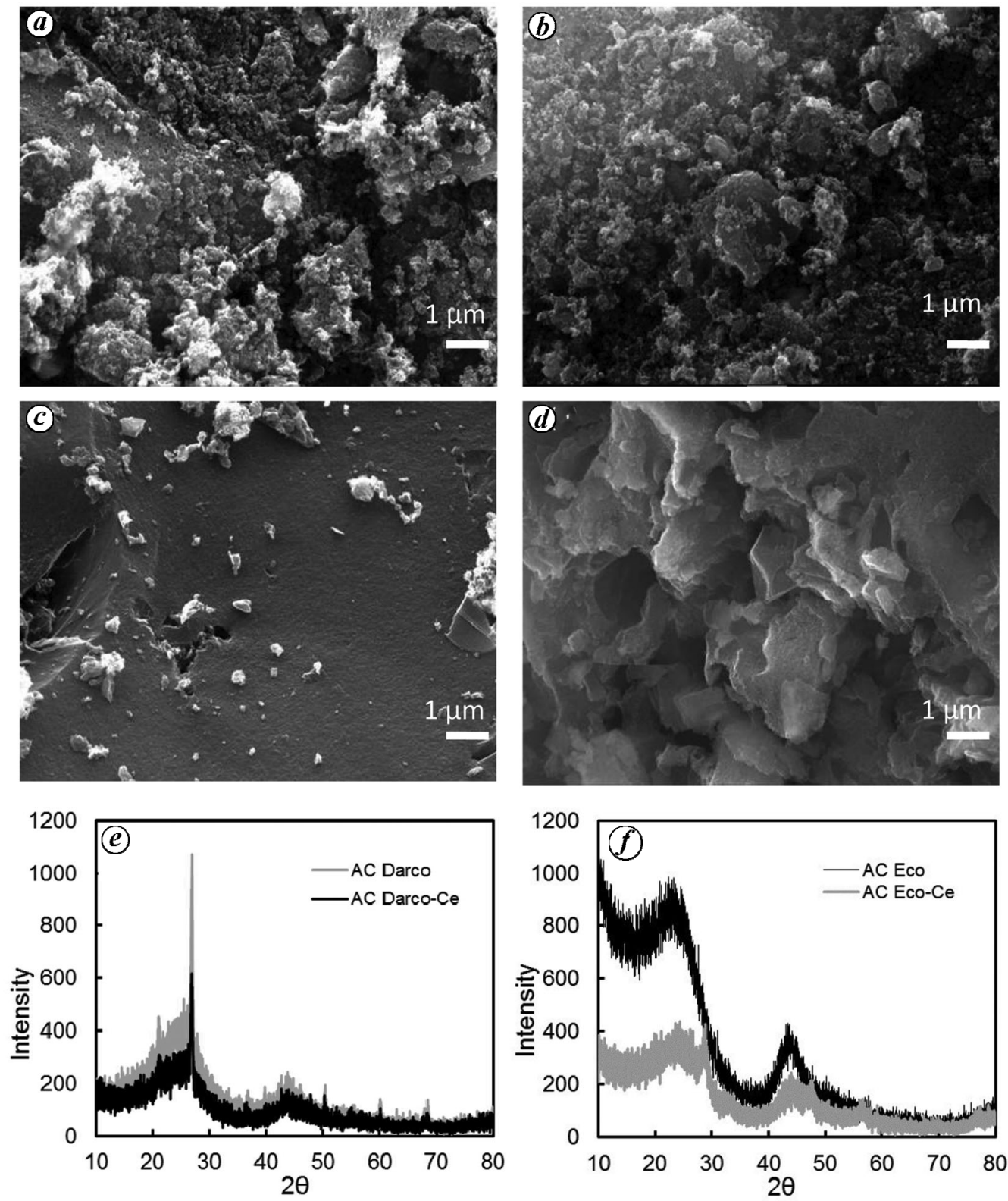

Figure 3 a-d. SEM images of $(\boldsymbol{a}) \mathrm{AC}_{\mathrm{Darco}},(\boldsymbol{b}) \mathrm{AC}_{\mathrm{Darco}}-\mathrm{Ce}$ composite, $(\boldsymbol{c}) \mathrm{AC}_{\mathrm{Eco}}$ and $(\boldsymbol{d}) \mathrm{AC}_{\mathrm{Eco}}-\mathrm{Ce}$ composite. $\boldsymbol{e}, \boldsymbol{f}, \mathrm{XRD}$ spectra of $(\boldsymbol{e}) \mathrm{AC}_{\text {Darco }}$ and $\mathrm{AC}_{\mathrm{Darco}}-\mathrm{Ce}$ composite and $(\boldsymbol{f}) \mathrm{AC}_{\mathrm{Eco}}$ and $\mathrm{AC}_{\mathrm{Eco}}-\mathrm{Ce}$ composite.

Table 1. Surface area of different activated carbon (AC) composites by multipoint BET analysis

\begin{tabular}{lccc}
\hline Composite & Specific surface area $\left(\mathrm{m}^{2} / \mathrm{g}\right)$ & Pore volume $\left(\mathrm{cm}^{3} / \mathrm{g}\right)$ & Pore diameter $(\AA)$ \\
\hline $\mathrm{AC}_{\mathrm{Eco}}$ & 833 & 0.44 & 21.10 \\
$\mathrm{AC}_{\mathrm{Eco}}-\mathrm{Ce}$ & 759 & 0.40 & 20.84 \\
$\mathrm{AC}_{\text {Darco }}$ & 334 & 0.24 & 29.29 \\
$\mathrm{AC}_{\text {Darco }}-\mathrm{Ce}$ & 335 & 0.27 & 31.72 \\
\hline
\end{tabular}

$\mathrm{AC}_{\mathrm{Eco}}-\mathrm{Ce}$ compared to $\mathrm{AC}_{\text {Darco }}-\mathrm{Ce}$ composite. This may be because the pore size (Table 1) of the former $(20.84 \AA)$ is smaller than that of the latter $(31.72 \AA)$, which can inhibit $\mathrm{F}^{-}$sorption by the composite.

Overall, it can be stated that the combined effect of ion exchange and greater extent of sorption, which depends on several factors as discussed above, is responsible for better performance of $\mathrm{AC}_{\mathrm{Darco}}-\mathrm{Ce}$ compared to that of $\mathrm{AC}_{\mathrm{Eco}}-\mathrm{Ce}$ composite. Figure 4 presents the conceptual $\mathrm{F}^{-}$ removal process by $\mathrm{AC}_{\text {Darco }}-\mathrm{Ce}$.

Column experiment was performed, where $10 \mathrm{mg} / \mathrm{l} \mathrm{F}^{-}$ was injected from the bottom of the column at a rate of 


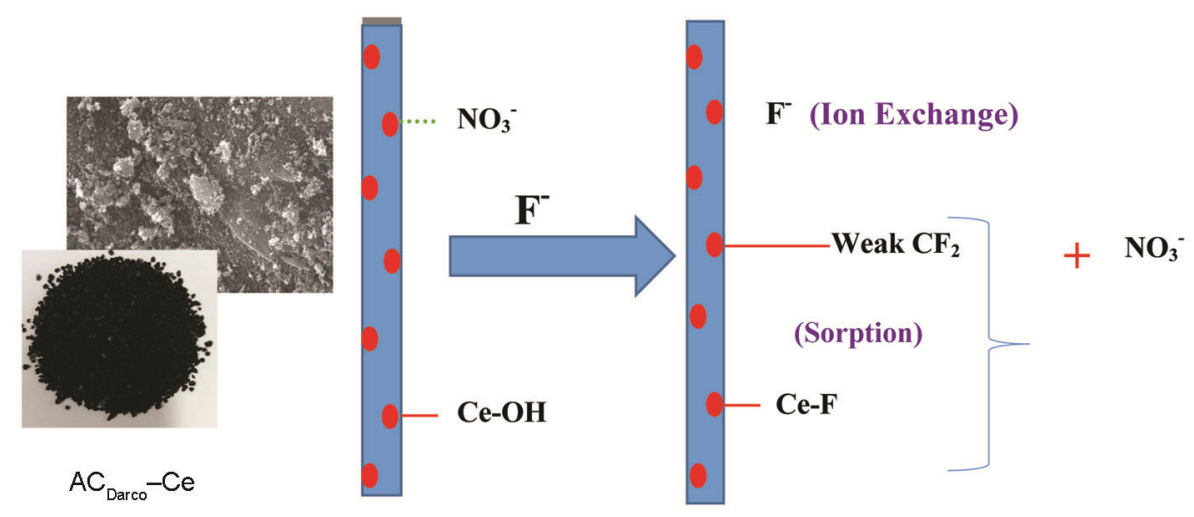

Figure 4. Conceptual schematic explaining fluoride removal by $\mathrm{AC}_{\mathrm{Darco}}-\mathrm{Ce}$ composite as a combination of different mechanisms.

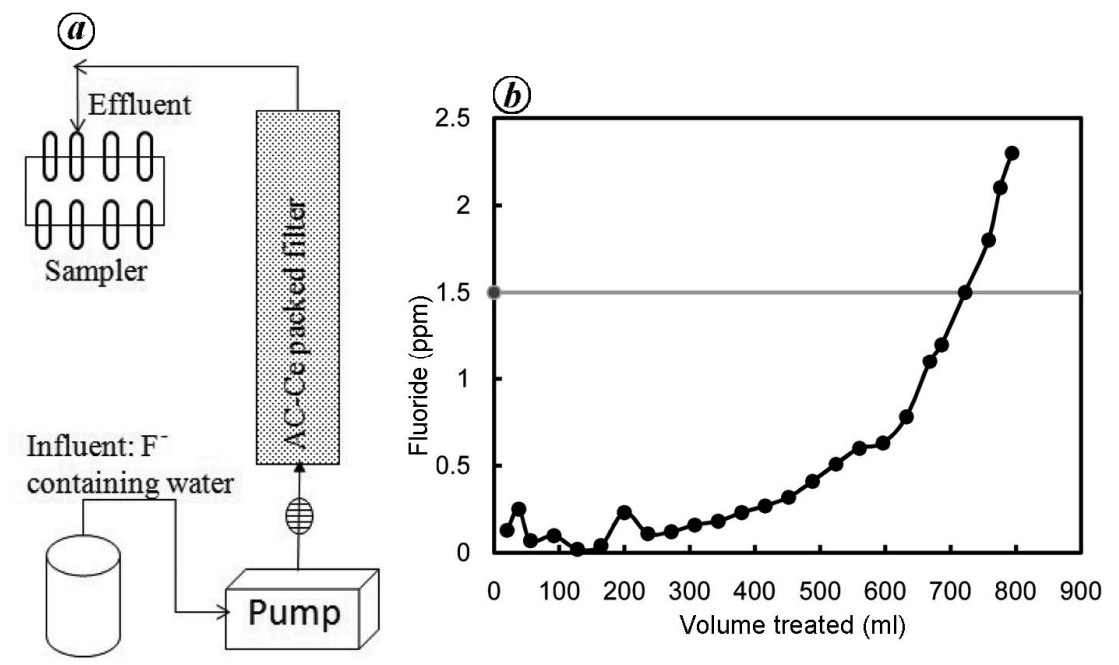

Figure 5. $\boldsymbol{a}$, Layout of the column experimental set-up. $\boldsymbol{b}, \mathrm{F}^{-}$concentration $(\mathrm{mg} / \mathrm{l})$ at the column effluent with respect to volume of water treated. $\mathrm{F}^{-}$concentration at the influent was maintained as $10 \mathrm{mg} / \mathrm{l}$.

$0.6 \mathrm{ml} / \mathrm{min}$ until the effluent $\mathrm{F}^{-}$concentration reached $1.5 \mathrm{mg} / \mathrm{l}$ at the outlet (Figure $5 a$ ). The result (Figure $5 \mathrm{~b}$ ) indicates that the $\mathrm{AC}_{\mathrm{Darco}}-\mathrm{Ce}$ composite packed column can treat up to $722 \mathrm{ml}$ of $\mathrm{F}^{-}$containing DI water. The mass balance of $\mathrm{F}^{-}$between influent and effluent water indicates that $1.29 \mathrm{mg}$ of $\mathrm{F}^{-}$is adsorbed per gram of $\mathrm{AC}_{\text {Darco }}-\mathrm{Ce}$ composite during its residence time within the column. The residence time of $\mathrm{F}^{-}$contaminated water within the column is $8 \mathrm{~min}$, whereas the time for equilibrium sorption is $3 \mathrm{~h}$. Our previous study ${ }^{5}$ showed that the pseudo second-order model fits the kinetics data better for $\mathrm{AC}_{\text {Darco }}-\mathrm{Ce}$ composite. The sorption capacity of $\mathrm{F}^{-}$ by the composite during 8 min duration is evaluated to be $0.75 \mathrm{mg} / \mathrm{g}$, considering the estimated model parameters (i.e. equilibrium sorption, $q_{\mathrm{e}}: 2.53 \mathrm{mg} / \mathrm{g}$ and rate of sorption, $k_{t}=0.021 \mathrm{mg} / \mathrm{g} / \mathrm{min}$ ) as reported in the previous study $^{5}$. A higher $\mathrm{F}^{-}$removal $(1.29 \mathrm{mg} / \mathrm{g}$ compared to an estimated value of $0.75 \mathrm{mg} / \mathrm{g}$ ) in the column is probably attributed to (i) higher relative dose of adsorbent in the column, and (ii) the combined effect of sorption along with dispersion during the transport of $\mathrm{F}^{-}$through the packed bed column.

Thus it can be concluded that impregnation of amorphous $\mathrm{Ce}$ and its homogeneous distribution within the $\mathrm{AC}_{\text {Darco }}-\mathrm{Ce}$ composite, along with the occurrence of ion exchange between $\mathrm{NO}_{3}^{-}$and $\mathrm{F}^{-}$can enhance the performance of the $\mathrm{AC}_{\text {Darco }}-\mathrm{Ce}$ composite. On the other hand, formation of crystalline $\mathrm{CeO}_{2}$ and small pore size of the $\mathrm{AC}_{\mathrm{Eco}}-\mathrm{Ce}$ composite inhibits $\mathrm{F}^{-}$sorption by the latter. Therefore, $\mathrm{AC}_{\text {Darco }}-\mathrm{Ce}$ composite can be embedded suitably in fixed-bed column as a filter medium for $\mathrm{F}^{-}$ removal.

1. Bhatnagar, A., Kumar, E. and Sillanpää, M., Fluoride removal from water by adsorption - a review. Chem. Eng. J., 2011, 171, 811-840.

2. Liao, X.-P. and Shi, B., Adsorption of fluoride on zirconium(iv)impregnated collagen fiber. Environ. Sci. Technol., 2005, 39, 4628-4632.

3. Wang, M., Yu, X., Yang, C., Yang, X., Lin, M., Guan, L. and Ge, M., Removal of fluoride from aqueous solution by $\mathrm{Mg}-\mathrm{Al}-\mathrm{Zr}$ triple-metal composite. Chem. Eng. J., 2017, 322, 246-253. 
4. Kalidindi, S., Vecha, M., Kar, A. and Raychoudhury, T., Aluminum-cerium double-metal impregnated activated carbon: a novel composite for fluoride removal from aqueous solution. Water Sci. Technol.: Water Suppl., 2017, 17, 115-124.

5. Raychoudhury, T., Boindala, S. P. and Kalidindi, S., Performance evaluation of metal impregnated activated carbon composite for removal of fluoride under different solution chemistry. Water Sci. Technol.: Water Suppl., 2017, 17(5), 1377-1385.

6. Inanya, M. and Raychoudhury, T., Application of activated carbon-metal composite for fluoride removal from contaminated groundwater in India. Int. J. Environ. Sci. Technol., 2018; https://doi.org/10.1007/s13762-018-2097-9.

7. Tripathy, S. S., Bersillon, J. L. and Gopal, K., Removal of fluoride from drinking water by adsorption onto alum-impregnated activated alumina. Sep. Purif. Technol., 2006, 50, 310-317.

8. Kang, D., Yu, X. and Ge, M., Morphology-dependent properties and adsorption performance of $\mathrm{CeO}_{2}$ for fluoride removal. Chem. Eng. J., 2017, 330, 36-43.

9. Viswanathan, N. and Meenakshi, S., Enhanced and selective fluoride sorption on $\mathrm{Ce}$ (iii) encapsulated chitosan polymeric matrix. J. Appl. Polym. Sci., 2009, 112, 1114-1121.

10. Zhang, S., Lu, Y., Lin, X., Su, X. and Zhang, Y., Removal of fluoride from groundwater by adsorption onto $\mathrm{La}$ (iii)-Al(iii) loaded scoria adsorbent. Appl. Surf. Sci., 2014, 303, 1-5.

11. Guo, X. and Chen, F., Removal of arsenic by bead cellulose loaded with iron oxyhydroxide from groundwater. Environ. Sci. Technol., 2005, 39, 6808-6818.

12. Yu, Y., Yu, L. and Chen, J. P., Adsorption of fluoride by $\mathrm{Fe}-\mathrm{Mg}$ La triple-metal composite: adsorbent preparation, illustration of performance and study of mechanisms. Chem. Eng. J., 2015, 262, 839-846.

13. Fiol, N. and Villaescusa, I., Determination of sorbent point zero charge: usefulness in sorption studies. Environ. Chem. Lett., 2009, 7, 79-84.

14. Koilraj, P. and Kannan, S., Aqueous fluoride removal using $\mathrm{ZnCr}$ layered double hydroxides and their polymeric composites: batch and column studies. Chem. Eng. J., 2013, 234, 406-415.

15. Alagumuthu, G. and Rajan, M., Equilibrium and kinetics of adsorption of fluoride onto zirconium impregnated cashew nut shell carbon. Chem. Eng. J., 2010, 158, 451-457.

16. Ma, Y., Wang, S.-G., Fan, M., Gong, W.-X. and Gao, B.-Y., Characteristics and defluoridation performance of granular activated carbons coated with manganese oxides. J. Hazard Mater, 2009, 168, 1140-1146.

17. Liu, H., Deng, S., Li, Z., Yu, G. and Huang, J., Preparation of Al-Ce hybrid adsorbent and its application for defluoridation of drinking water. J. Hazard Mater, 2010, 179, 424-430.

18. Wang, J., Xu, W., Chen, L., Jia, Y., Wang, L., Huang, X.-J. and Liu, J., Excellent fluoride removal performance by $\mathrm{CeO}_{2}-\mathrm{ZrO}_{2}$ nanocages in water environment. Chem. Eng. J., 2013, 231, 198-205.

19. Bo, L., Ran, L., Quan-Jun, L., Ming-Guang, Y., Bo, Z., Tian, C., Bing-Bing, L. and Jing, L., Study of high pressure structural stability of $\mathrm{CeO}_{2}$ nanoparticles. Chin. Phys. C, 2013, 37, 098003.

ACKNOWLEDGEMENTS. We thank Dr Ramakrishna, Global Ecocarb Pvt Ltd, Bengaluru for providing the $\mathrm{AC}_{\mathrm{Eco}}$ samples. We also thank the Dr Abhas Singh (IIT Kanpur) and Sophisticated Analytical Instrument Facility (SAIF), Cochin for providing instrumentation facilities.

Received 16 July 2018; revised accepted 3 April 2019

\section{Evaluation of high rate MBBR to predict optimal design parameters for higher carbon and subsequent ammoniacal nitrogen removal}

\author{
Sandip Magdum ${ }^{1, *}$ and V. Kalyanraman ${ }^{2}$ \\ ${ }^{1}$ Department of Technology, Savitribai Phule Pune University, \\ Pune 411 007, India \\ ${ }^{2}$ COE Biotechnology, R.D. Aga Research, Technology and Innovation \\ Centre, Thermax Ltd, Pune 411 019, India
}

The high rate moving bed biofilm reactor (MBBR) processes were designed for wastewater treatment to meet the past effluent discharge norms of biological oxygen demand (BOD) $<50 \mathrm{mg} / \mathrm{l}$. However, they are incapable of meeting current effluent discharge norms which consist of BOD $<10 \mathrm{mg} / \mathrm{l}$ and total nitrogen $<10 \mathrm{mg} / \mathrm{l}$. This study analyses the effect and variation of organic loading rate from $1.21 \mathrm{~kg}$ to $4.59 \mathrm{~kg}$ chemical oxygen demand $(\mathrm{COD}) /\left(\mathrm{m}^{3}\right.$ day $)$ and surface loading rate from $4.9 \mathrm{~g}$ to $24 \mathrm{~g} \mathrm{COD} /\left(\mathrm{m}^{2}\right.$ day $)$ on a high rate MBBR performance. The results of $C O D$ reduction $\left(C O D_{\text {red }}\right)$ and subsequent ammoniacal nitrogen reduction $\left(\mathrm{NH}_{3}-\mathrm{N}_{\text {red }}\right)$ were in the range of $65.4 \%$ to $87.8 \%$ and $11.8 \%$ to $47.2 \%$ respectively. The projected graphical optimization defines the design parameters for $M B B R$ and also predicts $C O D_{\text {red }}$ and subsequent $\mathrm{NH}_{3}-\mathrm{N}_{\text {red }}$. By understanding this subsequent $\mathrm{NH}_{3}-\mathrm{N}_{\text {red }}$ in the MBBR system, future designs for engineering technologies will be aided.

Keywords: Graphically, HRT, MBBR, optimized, organic load, wastewater.

THE moving bed biofilm reactor (MBBR) technology is commonly known for its high rate wastewater treatment process. In the last decade of the 20th century, this process was studied with great interest, eventually developing in its own technological space. In the 'moving bed biofilm' process, a suspended, porous polymeric is used as a carrier which then moves continuously in the aeration tank, causing the active biomass to grow as a biofilm on the surface of the carrier ${ }^{1}$. In addition, more than $90 \%$ of the biomass is attached to the media rather than suspended in the liquid ${ }^{2}$. A number of these characteristics has made the MBBR process more acceptable in the current era. It is a complete mix, compact, with continuous flow through, has high stability against load variation, lower process head loss, and less reactor maintenance including air grid cleaning. There is no sludge recycling, and there is an easy retrofit for existing activated sludge process (ASP) plants with nitrifiers retention and high solids retention time (SRT). 